\title{
The State of Entrepreneurship and Innovativeness in Montenegro
}

\author{
Sanja Pekovic \\ University of Montenegro, Montenegro \\ Jelena Jovanovic \\ University of Montenegro, Montenegro \\ Zdravko Krivokapic \\ University of Montenegro, Montenegro \\ Aleksandar Vujovic \\ University of Montenegro, Montenegro
}

\begin{abstract}
European business sector pays an ever more increasing attention to competences such as sense of initiative and entrepreneurship but Western Balkan countries as transition countries from state regulated towards market economy, have a high level of resistance to private initiatives and entrepreneurship. The Erasmus REBUS project aims at developing, testing, validating and mainstreaming holistic and needs driven open learning modules to promote entrepreneurship competences of ICT and engineering graduates at the interface of academic education and learning in practical business contexts. University of Montenegro as partner on the Rebus project is involved in research about current situation of entrepreneurship and innovativeness in Montenegro. Accordingly, we performed research which consists three parts: Online questionnaires, Desk research and Interview. Target groups for the research are: students, $\mathrm{HEl}$, enterprises, administration, Chamber of Commerce... In this paper are presented results of that research with special focus on results obtained in online questionnaires.
\end{abstract}

Keywords: entrepreneurship, innovation, desk research, questionnaire JEL classification: L26

Acknowledgments: Project "ReBUS" co-funded by the Erasmus+ Programme of the European Union.

\section{Introduction}

The history of entrepreneurship has its roots from the 17th and 18th centuries and through research works by Richard Cantillon and Adam Smith. However, the greater emphasis of entrepreneurship in theoretical sense we found in the period of the end of 19th and the beginning of 20th century. The term of entrepreneurship is especially emphasized through practical examples and actions in the end of 20th century and at the beginning of 21 st century.

The concepts of entrepreneurs and entrepreneurship have changed in the last few centuries since the first definitions appeared. The concept of entrepreneurship is mostly related to the process of implementing a new business arrangement. The main functions of entrepreneurship are in relation with foresight, risk acceptance, innovation and learning. In order to establish these functions, the synergistic action of talent, technology, capital and "know-how" approach should be defined. The 
importance of entrepreneurship is also reflected by an extraordinary fact that $75 \%$ of jobs in the world are created through entrepreneurial ventures.

There is a constant dilemma about whether an entrepreneur is born or becomes. There is also a question of the level of correlation between academic education and success in entrepreneurship. If we are talking about the underling foundation of entrepreneurship, then we have three pillars (Vujović et al., 2014):

- Excellent knowledge of the needs of customers, markets, technology, technics etc.,

- Experience, passion to the work and persistence, as well as the investment of enormous work,

- Ideas and objectives, finding and striving to the unused market conditions.

University of Montenegro as partner on the Rebus project (ReBUS project, 2017) is involved in research about current situation of entrepreneurship and innovativeness in Montenegro. Accordingly, we performed research which consists three parts:

- Online questionnaires,

- Desk research,

- Interview.

Target groups for the research are: students, HEl, enterprises, administration, Chamber of Commerce...

\section{Results of Desk Research}

Desk research about entrepreneurship in Montenegro is realized by 3 professors of the University of Montenegro. Desk research encompasses 4 topics as following:

- Part 1: Entrepreneurship in practice

- Part 2: Entrepreneurship Education

- Part 3: Learning Technologies and blended learning in Higher Education

- Part 4: Job related Competences, Informal learning and Validation

Here is presented some of the most important information about each topic.

\section{Part 1: Entrepreneurship in practice}

Montenegro has developed a Strategy of development of vocational education (2015-2020) (Ministry of Education of Montenegro, 2014a). Montenegro has also developed Strategy for lifelong entrepreneurial learning for the period 2015-2019 (Ministry of Education of Montenegro, 2014b). The Entrepreneurial learning in Montenegro during the last 15 years has undergone several phases of development.

There are many organizations in Montenegro that offer a variety of courses to employers through trainings, seminars, workshops and round tables in order to develop the business in Montenegro.

Entrepreneurship is represented in primary education as an optional teaching course in 8 . Class of elementary school. Starting from 2012/2013. in all secondary vocational schools in the framework of the subject Entrepreneurship was implemented the program "Young Entrepreneurs". In the framework of the program, was created Manual for students and Manual for Teachers and there also were conducted training for teachers, school directors and entrepreneurs / partners. The key competence "Entrepreneurship" is recognized and included in the new / revised programs for vocational education.

Insufficient progress in this field has been made in the study of entrepreneurship in gymnasium, in the development of social entrepreneurship and in the creation of a web portal on entrepreneurial learning. 


\section{Part 2: Entrepreneurship Education}

There are some courses in Montenegro focused on Entrepreneurship at University of Montenegro as following:

- "Entrepreneurship and Business" is direction in the final year of undergraduate studies at the Faculty of economy, University of Montenegro (4 years)

- Study program Entrepreneurship at the Master level of Economics at the Faculty of Economics

- Teaching course of Entrepreneurship at the Undergraduate Studies of Management at the same Faculty of Economics

There are some teaching courses in the field of Entrepreneurship at the University of Donja Gorica (UDG). There is also master study program called "Entrepreneurial Economy" (120 ECTS) at the same faculty. At the Faculty of Information Systems and Technologies (UDG) in the main study program, the course "Entrepreneurial Management" is in the fifth semester (4 ETCS) as a elective exam.

At the University of Mediteran there are also some courses focused on entrepreneurship:

- "Entrepreneurship in Tourism and Hospitality" (IV semester, 5 ECTS) at the Faculty of tourism, University "Mediteran"

- "Entrepreneurship and Small Business" (6ECTS) at the Faculty of Business Studies, University "Mediteran"

- "Enterpreneurship" (5 semester, 5 ECTS) at the private Faculty for business and toursim in Budva

- "Entrepreneurship" is course on each study programs at the Faculty for Mediterranean Business Studies.

Part 3: Learning Technologies and blended learning in Higher Education

At the University of Montenegro, software Moodle is used sporadically. It is not systematically prescribed obligation for using this software. Therefore there is no statistics in this regard. There is no one Accredited Program in Montenegro which has the character of e-learning. According new study model, which will start from study year 2017/2018 at the University of Montenegro, new curricula of some courses will consists practical training performed in facilities of external parties.

So, it is obligation to involve practical learning in every study program. Practical learning will be performed in facilities of chosen business system.

Part 4: Job related Competences, Informal learning and Validation

There is no one validation system in Montenegro in the area of entrepreneurial skills and competences.

There are no assessment systems for these skills / competences in Montenegro.

\section{Results of Interview}

The interview is performed with 1 entrepreneur (business person), 2 professors (University of Montenegro) 1 student of University of Montenegro and 1 member from Chamber of Commerce. There were 5 questions leach with more than 1 sub question) as following.

1. How would you describe the general demand for entrepreneurship education? 
Most of the interviewees find that there is a lack of entrepreneurship education in Monenegro. Actually, most of them said that there are the least learning about entrepreneurship on universities that are not strictly focused on economics and business.

2. How can the concept of Entrepreneurship Education be supported?

All interviewees said that the Business sector can enable HEl their facilities to realize practices. Most of interviewees consider that the teaching course related to the entrepreneurship as obligatory course in all study programs should be defined by some strategies, for example, Strategy of high education or Strategy of university's development. All interviewees agreed that people from business sector should be more integrated in the courses. There were different thinking about the type of contribution, but they mostly agree that each course, where is it possible should include practice in some enterprises.

3. How should Entrepreneurship Education be provided?

In this section there were different proposals of interviewees. HE-sector can provide better educational approaches related to the entrepreneurship education on the following ways:

- Inclusion of compulsory teaching course Entrepreneurship in curricula

- Modify certain ECTS in such a way that the themes of entrepreneurship work as much as possible

- Establishment of cooperation between $\mathrm{HEl}$ with selected successful companies that will enable students to practice

- Defining the obligation to conduct practical teaching in enterprises according selected teaching courses

- Providing professional assistance for the development of their own business to students on final years of study

4. What is the right place and the best methodology to deliver Entrepreneurship Education?

Some interviewees believe that it is the best way to learn about entrepreneurship through practice in selected enterprises. The others think that it must still be implemented by combination of the method of individual learning within institutions of teaching and practice in selected enterprises. All respondents agreed that the best and most interesting learning method is using a mix of different learning modalities using compulsory practice in selected enterprises.

5. Why Entrepreneurial Competences are important and how would you validate them?

All interviewees have opinion that asses of entrepreneurial competences should be realized by some tests and/or interviews. All respondents consider that it is very useful to certify entrepreneurial competences because certification is a proof of real competences. It can also be very useful to establish a public list of people who have certified competences.

\section{Results of Online Questionnaires}

REBUS is a research and development project aiming at developing a learning approach for entrepreneurship in Higher Education institutes. It aims at understanding how familiar stakeholders in Higher Education (e.g. professionals as well as students) are with the concept of entrepreneurship and entrepreneurial 
competences in connection with web-based learning environments as well as with approaches and instruments for validation of learning outcomes in their practice.

The Questionnaire is distributed to all partners' countries at Erasmus + Rebus project. There were 809 respondents. It is consists of 5 parts:

1. Introduction and statistical background data

2. Entrepreneurship and Entrepreneurship competences

3. "Learning entrepreneurship" - Acquisition of entrepreneurial competences

4. Validation of competences

5. Digital learning

There were 54 responds from Montenegro as it is presented in figure 1.

Figure 1

Type of Responds from Montenegro

Feld-Zusammenfassung für organisation

You work in

\begin{tabular}{lll}
\hline & & \\
Antwort & Anzahl & Prozent \\
Higher Education (1) & 18 & $33.33 \%$ \\
Enterpriselbusiness (2) & 8 & $14.81 \%$ \\
Iama student (3) & 21 & $38.89 \%$ \\
Administration (4) & 3 & $5.56 \%$ \\
Chamber of commerce (5) & 2 & $3.70 \%$ \\
Sonstiges & 2 & $3.70 \%$ \\
keine Antwort & 0 & $0.00 \%$ \\
Nicht gezeigt & 0 & $0.00 \%$
\end{tabular}

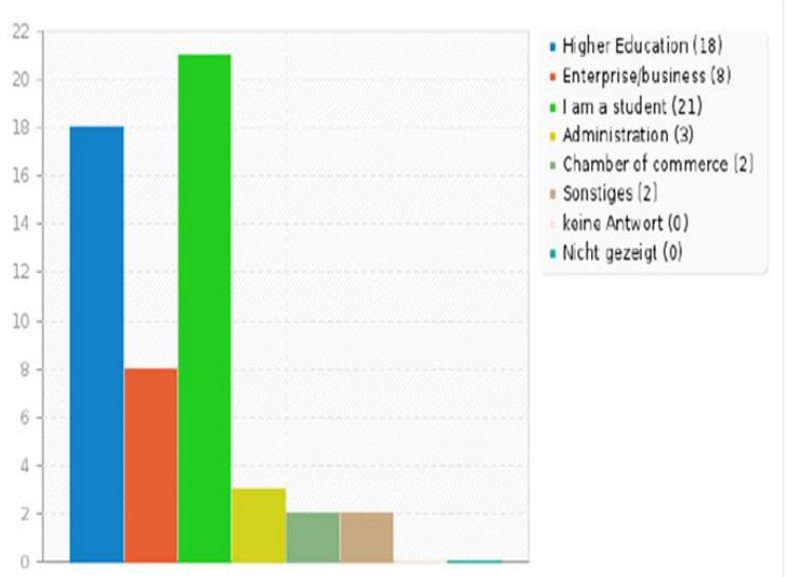

Source: ReBUS project (2017),

Here, we are given some interesting answers.

As we can see, most of the respondents said that they heard about entrepreneurship as competence (figure 2). 
Figure 2

Entrepreneurship as Competence

Have you ever heard about "entrepreneurship and sense of initiative" as a competence (required to work successfully in your economy)?

$\begin{array}{lll}\text { Antwort } & \text { Anzahl } & \text { Prozent } \\ \text { Yes (A1) } & 41 & 75.93 \% \\ \text { No (A2) } & 13 & 24.07 \% \\ \text { keine Antwort } & 0 & 0.00 \% \\ \text { Nicht gezeigt } & 0 & 0.00 \%\end{array}$

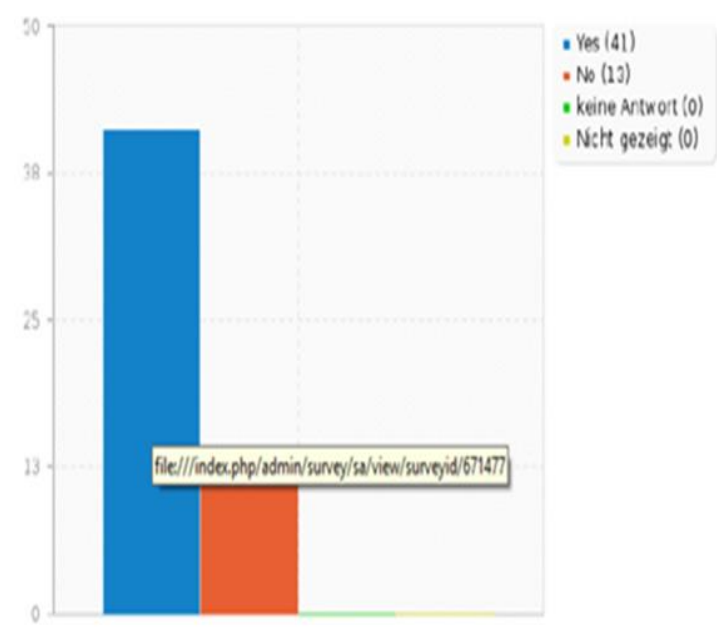

Source: ReBUS project (2017),

Most of respondents said that vision is most important for persons who have an entrepreneurial mindset (figure 3).

Figure 3

Most Important Aspects for Persons Who Have Entrepreneurial Mindset

Which aspects and competences you consider most important for persons who have an entrepreneurial mindset?[Reihentolge 1]

\begin{tabular}{lll|} 
Antwort & Anzahl & Prozent \\
\hline Looking for Opportunities (A1) & 5 & $9.26 \%$ \\
Creativity (A2) & 1 & $1.85 \%$ \\
Vision (A3) & 13 & $24.07 \%$ \\
Valuing ideas (A4) & 1 & $1.85 \%$ \\
Ethical and sustainable thinking (A5) & 0 & $0.00 \%$ \\
Self awareness an efficacy (A6) & 4 & $7.41 \%$ \\
Motivation and perseverance (A7) & 5 & $9.26 \%$ \\
Mobilising resources (A8) & 3 & $5.56 \%$ \\
Financial and economic literacy (A9) & 3 & $5.56 \%$ \\
Mobilising others (A10) & 1 & $1.85 \%$ \\
Taking initiative (A11) & 7 & $12.96 \%$ \\
Planning and management (A12) & 1 & $1.85 \%$ \\
Coping with ambiguity, uncertainty and risk (A13) & 3 & $5.56 \%$ \\
Working with others (A14) & 5 & $9.26 \%$ \\
Learning through experience (A15) & 2 & $3.70 \%$ \\
Nicht gezeigt & 0 & $0.00 \%$
\end{tabular}

Source: ReBUS project (2017),

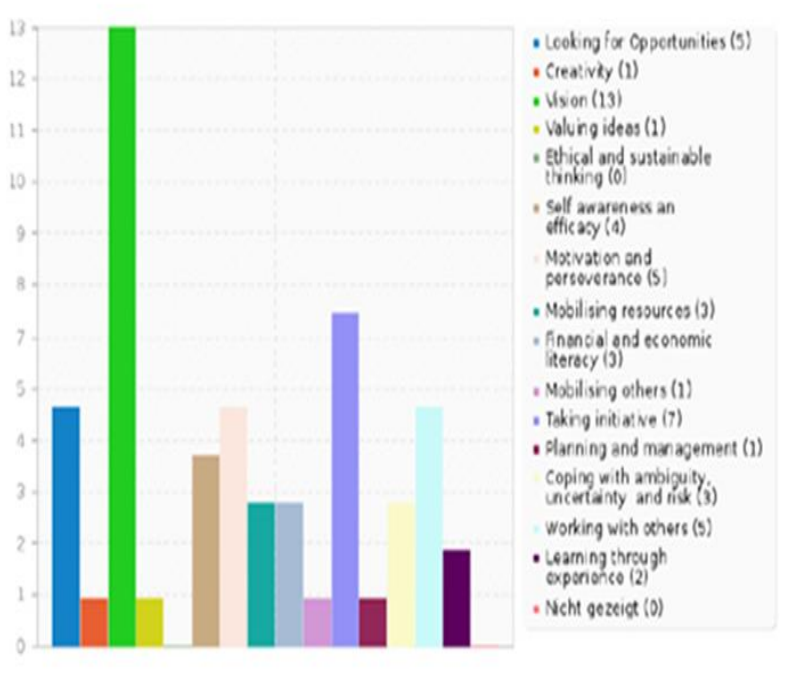

Answer on the question "Are you aware of any learning programme to promote the acquisition of entrepreneurial competences" was "No" in more than $80 \%$ (figure $4)$. 
Figure 4

Awareness of Learning Programme for Promoting Entrepreneurial Competences

Are you aware of any learning programme, learning activity to promote the acquisition of entrepreneurial competences?

\begin{tabular}{lll}
\hline Antwort & Anzahl & Prozent \\
Yes (A1) & 10 & $18.52 \%$ \\
No (A2) & 44 & $81.48 \%$ \\
keine Antwort & 0 & $0.00 \%$ \\
Nicht gezeigt & 0 & $0.00 \%$
\end{tabular}

Source: ReBUS project (2017)

Most of respondents (66\%) said that validation of competences is very important (figure 5).

Figure 5

Importance of validation of competences
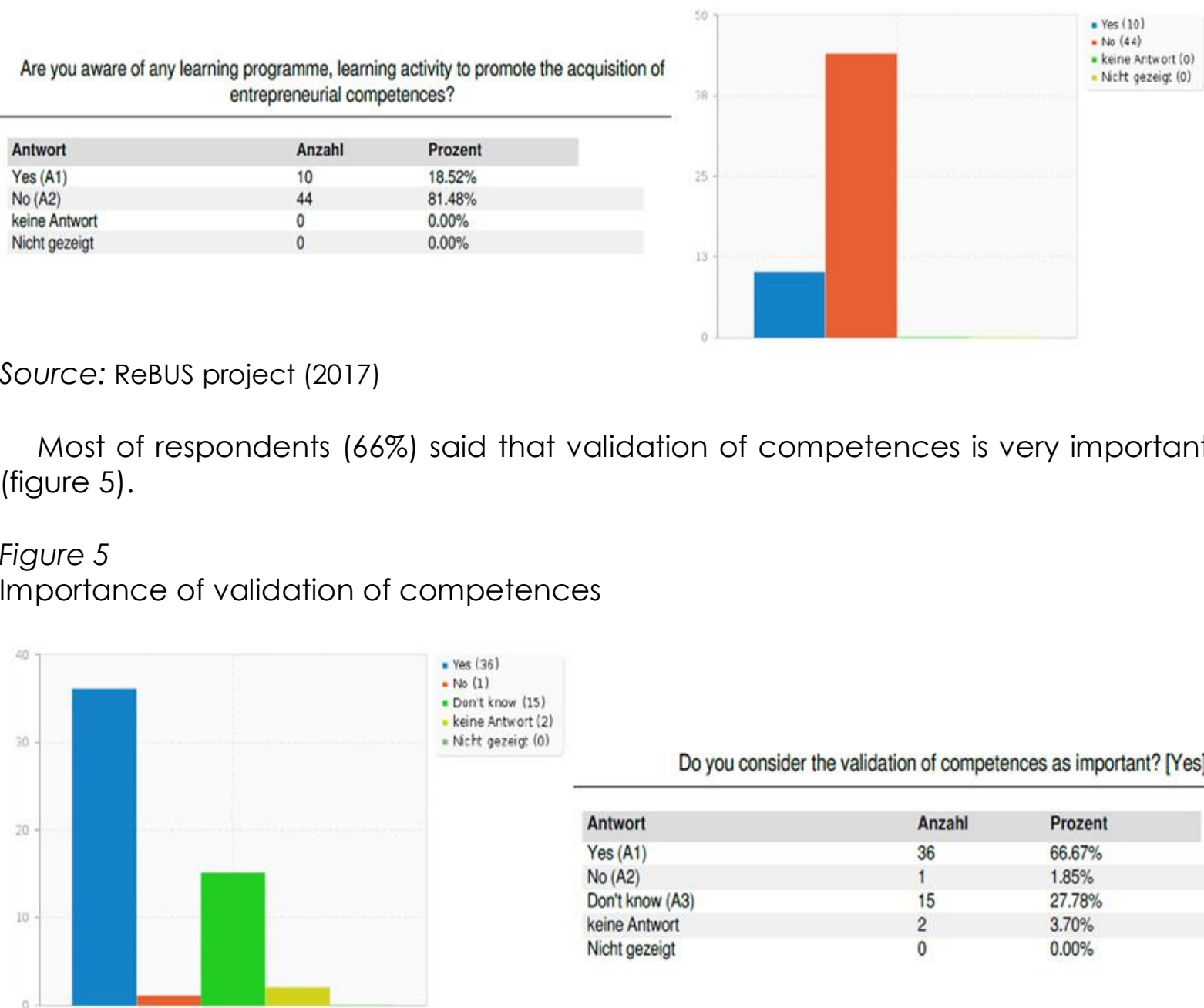

Source: ReBUS project (2017)

Unfortunately, most of respondents don't have any idea about validation of competences (figure 6).

Figure 6

Having idea about validation of competences

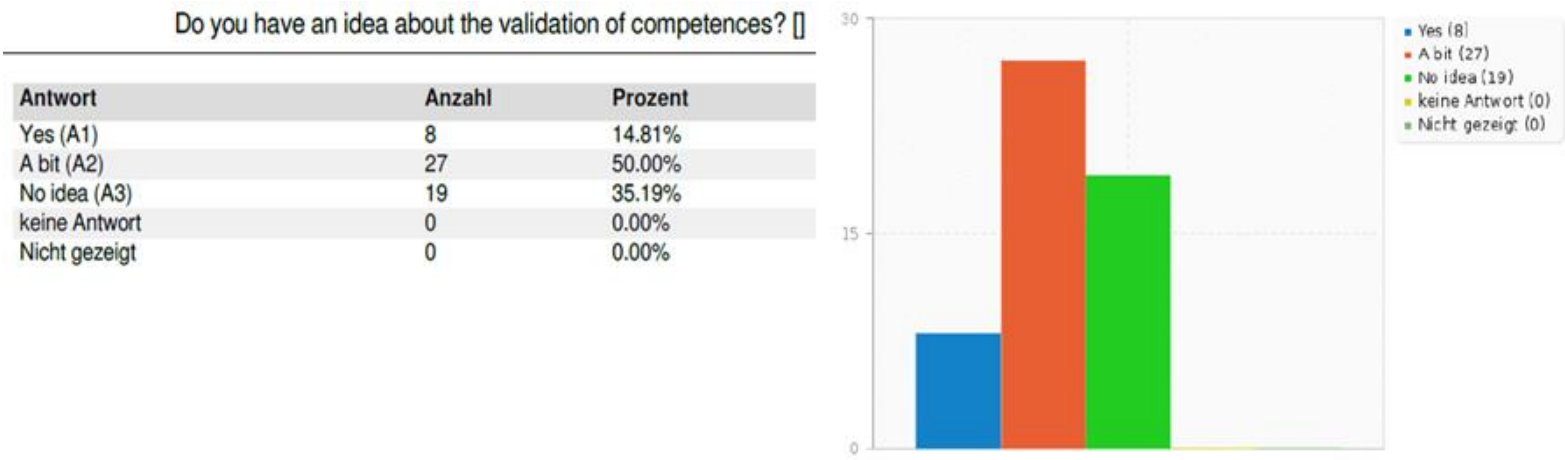

Source: ReBUS project (2017) 


\section{Conclusion}

European business sector pays an ever more increasing attention to competences such as sense of initiative and entrepreneurship. The recommendation 2006/962/EC on key competences for lifelong learning highlights paramount importance of these key competences for employability. These competences related to entrepreneurship play a paramount role in EU neighboring countries in their development process towards higher performing market economies and convergence with EU economic and social standards. Western Balkan countries, as transition countries from state regulated towards market economy, have a high level of resistance to private initiatives and entrepreneurship and because of that the Rebus project will give strong support to develop entrepreneurship competences in Western Balkan countries and Montenegro.

According to the results presented in three parts of the research we found that there is a certain pre-knowledge about entrepreneurship in Montenegro and there are many already done in this field, especially in primary and secondary schools, as well as in the part of defining strategies related to the entrepreneurship. However, there is still a lot of spaces for improving entrepreneurship, especially in higher education and concrete practical work. There are some common opinions for raising the level of entrepreneurship in Montenegro, as following:

- Including a compulsory teaching course about entrepreneurship in $\mathrm{HEl}$,

- Promote entrepreneurship through other related courses,

- Provide students with more practice in specific companies,

- Enable seminars and workshops on the theme of entrepreneurship,

- Supporting of the best selected business plan,

- Creating business clubs,

- Defining entrepreneurship competences,

- Establish validation system for entrepreneurship competences.

The Rebus project is just on starting phase and during next 2 years all or most of these elements will be realized.

\section{References}

1. Vujović, A., Perović, M., Krivokapić, Z., Jovanović, J. (2014), "Industrijski inženjering", Univerzitet Crne Gore, Mašinski fakultet Podgorica.

2. ReBUS project (2017), available at: http://www.rebusproject.net/ (17 May 2017)

3. Ministarstvo prosvjete Crne Gore (2014), ,Strategija razvoja stručnog obrazovanja u Crnoj Gori", available at:

http://www.seecel.hr/UserDocslmages/Documents/Strategija_razvoja_strucnog_obra zovanja_Crna-Gora.pdf/ (17 April 2017)

4. Ministarstvo prosvjete Crne Gore (2014), ,Strategija za cjeloživotno preduzetničko učenje", available at: http://nasme.me/wp-content/uploads/2015/01/STRATEGIJA-ZACJELOZIVOTNO-PREDUZETNICKO-UCENJE-2015-2019.pdf/ (13 April 2017)

\section{About the authors}

Dr Sanja Pekovic has a Ph.D. in Economics from the University Paris-EST. She is Assistent Professor at the University of Montenegro. Between 2006 and 2011, she was Researcher at the Center for Labor Studies (Centre d'Eudes de I'Emploi) and Lecturer at the University Paris-EST. In 2006, she obtained a Master's degree from the Ecole Nationale Des Pontset Chaussées and University of Paris-EST Marne-la-Vallée. Her research interests are within the field of quality and environmental economics, 
economics of innovation, applied econometrics, and on this topic she has published in international journals. Author can be contacted at psanja@ac.me

Dr Jelena Jovanovic has Ph.D. at the Faculty of Mechanical Engineering Podgorica. She is Assistent Professor at the University of Montenegro. Her research interests are within the fields of Managements System standards and Performance Management System. She was consultant in more then 15 projects related to Management Systems implementation according ISO 9001, ISO 14001, ISO 17025, ISO 17020 standards and HACCP. She was engaged in many scientific research projects. She published more then 40 articles in international journals and international conferences and more then 50 articles in national journals and national conferences. Author can be contacted at sjelena@t-com.me

Zdravko Krivokapic is Doctor of Philosophy - Doctor of Science in Engineering from the Faculty of Mechanical Engineering. He is Full professor at University of Montenegro. Actively works with quality, quality management system, quality of education, informatics and accreditation. He is President of Board of Accreditation Body of Montenegro. He is member of Board for establishment and improvement of quality system of University of Montenegro. He is a president of national Conference of Quality (SQM) and International Quality Conference (ICQME). He is editor of International Journal for Quality Research. Author can be contacted at zdravkok@ac.me

Aleksandar J. Vujovic, graduated at the Faculty of Mechanical Engineering in Podgorica in 2000, at Department of Production Engineering. Master's thesis entitled "Nonconformity macro control models as a basis for improving the QMS", defended at the Faculty of Mechanical Engineering in Podgorica in 2004. He earned his doctorate at the Faculty of Mechanical Engineering in Podgorica in 2008. For his doctoral dissertation was awarded with the "Trimo". From 2000 to 2008 he worked as a teaching assistant, when he became a professor of: industrial engineering, flexible manufacturing systems, integrated systems management expertise and laboratory practice. Author can be contacted at aleksv@ac.me. 